\title{
Educating the children of migrants in China and the United States: a common challenge?
}

\author{
Jennifer Holdaway ${ }^{1,2}$
}

Received: 8 February 2018 / Accepted: 27 February 2018 / Published online: 25 June 2018 (C) The Author(s) 2018

\begin{abstract}
The education of the children of migrants is a policy issue of great importance in both China and the United States. While first generation migrants have generally completed their education in the place of origin, and some may return, their children will generally remain in the receiving place. Both pragmatic and moral considerations therefore require that schools equip them to participate fully in society as workers and citizens. This paper considers what we know about the education of children of low-skilled international labor migrants in the United States and the children of rural-urban migrants in China. It finds that although one migration flow is international and the other internal, the similar background characteristics of migrants create common challenges in both contexts; and the structure of both education systems serves to exacerbate underlying socio-economic inequalities. Residential segregation, unequal funding and formal and informal tracking processes concentrate migrant children in poor quality schools, resulting in low average levels of attainment and high drop-out rates. There are some obvious steps that could be taken in China to expand opportunities for migrant children, especially with regard to the transition to post-compulsory education, which is still constrained by their parents' household registration status (hukou). However, the experience of the United States shows that expanding access, while necessary, is not sufficient to level the playing field. To do this, targeted investments must be made to meet the specific educational needs of migrant children.
\end{abstract}

Jennifer Holdaway

Jennifer.holdaway@area.oxford.ac.uk

1 School of Interdisciplinary Area Studies, University of Oxford, Oxford, UK

2 Institute of Geographic Sciences and Natural Resources Research, Chinese Academy of Sciences, Beijing, China 
Keywords Migrants $\cdot$ Children $\cdot$ Education $\cdot$ Social mobility $\cdot$ China $\cdot$ United States

\section{Introduction}

China and the United States are most often discussed in terms of their differences, but there are areas in which the two countries face similar challenges, and one is in managing the impacts of large scale population migration (Roberts 1997). A major challenge associated with this is integrating the children of low-skilled labor migrants into the education system. First generation migrants will have been educated primarily in their place of origin and have limited opportunities for further study. But for their children, schools are a crucial site for both labor market preparation and socio-cultural integration. When children of migrants make up a substantial proportion of the school-age population, and of the future citizenry and workforce, the success of school systems in integrating them has important repercussions for economic development, social stratification and social cohesion. This is especially true in modern, post-industrial economies where a higher secondary level credential is the minimum qualification for employment that provides a decent standard of living and post-secondary education is increasingly a prerequisite for attaining middle class status. In the United States, for example, analysis by the Bureau of Labor Statistics (2017) shows that individuals with a university degree earn an average of $\$ 1156$ per week, compared with $\$ 692$ for those with only high school and \$504 for those without a high school diploma.

Given the importance of education systems in migrant integration, this article considers the extent to which similar challenges are involved in providing education for the children of rural-urban labor migrants in China and children of low-skilled international migrants in the US, and what can be learned from juxtaposing the two experiences. It also references some of the relevant research on Europe. The analysis draws on research conducted as part of the Social Science Research Council's Working Groups on Education and Migration (Alba and Holdaway 2009; Holdaway et al. 2009), and Migration and Development (DeWind and Holdaway 2008); the Immigrant Second Generation in Metropolitan New York (Kasinitz et al. 2008); the Children of Immigrants in Schools project (Alba and Holdaway 2013); and the CASSSSRC Common Concerns Seminar Series (Zheng et al. 2016). ${ }^{1,2}$

\footnotetext{
1 This is a revised and substantially updated version of a commentary previously published in Chinese as, "Common Challenges: Demographic Change, Social Stratification and the Education of Migrant Children in China and the United States," in Zheng Zhenzhen, He Zhenyi and Zhang Zhanxin, eds., Comparative Research on Migration in China and the United States. Beijing: China Social Sciences, 2016.

2 These projects received funding from the Andrew W. Mellon Foundation; the United States National Science Foundation, the Nuffield Foundation, the Ford Foundation and the Chinese Academy of Social Sciences.
} 


\section{Population migration and the children of immigrants in the US and China}

As the result of high rates of immigration over the last 50 years, the number of foreign born people in the US has been steadily increasing, reaching $13.4 \%$ of the population in 2015 (Pew Research Center 2017), Although there has also been an influx of highly skilled migrants, it is the integration of low-skilled workers that is generally seen as presenting the major challenge. Migrants from Mexico and other Central and South American countries, (collectively referred to as Latinos or Hispanics), who generally have relatively low levels of education and income, made up $51 \%$ of the foreign-born population in 2015 (Pew Research Center 2017). Because of falling birthrates among the native-born, children of immigrants make up an even higher percentage of the school age and young adult population. In 2014, $24 \%$ of children under 18 had at least one foreign-born parent, an increase of $45 \%$ since 1994; and $51 \%$ of these children had parents from Mexico or Central America (Woods and Hanson 2016). Because more than half these children of immigrants live in just ten metropolitan areas, they now form the majority of students in many urban schools (Orfield and Lee 2007).

Because of China's size, regional diversity, and uneven development, the nature and implications of internal migration strongly resemble those of international migration (Roberts 1997). After reform and opening up in the late 1970s, the relaxation of controls on population movement between rural and urban areas, and rising demand for manufacturing, construction and service workers, led to a growing tide of labor migration (Murphy 2002; Solinger 1999). In 2016, there were 245 million migrants out of a population of 1.382 billion people, $81.3 \%$ of them from rural areas (Department of Service and Management of Migrant Population 2017). ${ }^{3}$ As in the United States, migrants make up a large percentage of young people in urban areas and will form the core of the labor force as the nation ages. Growing numbers of migrants are now settling in cities with their children: in 2015 there were 20 million migrant children (now often referred as suiqian zinu), or one in eight urban children (Pan 2017). In many cities the percentage is much higher. In 2012, roughly four out of ten children in Shanghai and three out of ten in Beijing were migrant children (Zhou and Wang 2016).

With a few exceptions (DeWind and Holdaway 2008; Pieke and Mallee 1999; Roberts 1997; Solinger 1999), internal and international migration flows have been separate topics of research and the way in which children of immigrants have been considered within these two streams is also somewhat different. In the US, the focus has been almost entirely on children of immigrants in the receiving place. Children who do not migrate with their parents are largely ignored, although they have become a sub-category of research on transnational families and in the literature on chains of care [for example, Carling et al. (2012), Parrenas (2005), Smith (2006)]. But children born to immigrants in the US are citizens at birth and the government

\footnotetext{
${ }^{3}$ Migrants are usually defined as people who have spent more than 6 months living away the place where their hukou is registered.
} 
is therefore under both economic and moral pressure to integrate them. As a result, a small research industry has grown up that analyzes their educational attainment and its determinants, often comparing progress across generations as a way of assessing social mobility and socio-cultural integration [for example, Gans (1992), Gibson (1988), Louie (2004, 2012), Kasinitz et al. (2008), Portes and Rumbaut (2006), Portes and Zhou (1993), Rumbaut and Portes (2001), Suarez-Orozco and SuarezOrozco (2001), Zhou and Bankston (1999)].

For many years, although it was often framed as an analysis of the interaction between immigrant groups and the "context of reception" (Portes and Rumbaut 2006), research on the integration of migrants was conducted within individual countries and so many fundamental characteristics of the institutional and policy context were held constant. As a result, the focus of this work was mostly on how the characteristics of immigrants (level of education, work experience, language, religion, cultural orientations, social networks and capital, etc.) explained outcomes including labor market participation and income, and political participation, as well as, later, the educational and other outcomes of their children (Gans 1992; Gibson 1988; Kasinitz et al. 2008; Portes and Rumbaut 2006; Rumbaut and Portes 2001; Zhou and Bankston 1999). A key question in the study of the children of immigrants, especially those from low-income families, has been whether they will achieve social mobility or experience "segmented" assimilation into the lower rungs of America society (Gans 1992; Kasinitz et al. 2008; Portes and Zhou 1993).

More recently there has been a trend towards cross-national comparison of processes of integration and analysis of the role of institutional arrangements and policies in shaping patterns of integration among children of immigrants. This began in Europe because immigrants from the same countries (in particular Turkey and Morocco) were migrating to European nations with different educational systems and social protection regimes, creating a natural experiment (Crul 2010; Crul and Schneider 2009; Crul and Vermeulen 2003). Research initially compared policies directed at immigrants, including entrance and citizenship requirements, language education, and policies of multiculturalism (Castles and Miller 2003; Favell 2001; Freeman 2004). Later, researchers became interested in cross-national differences in general institutional and policy arrangements that may disproportionately affect children of immigrants, including education systems, labor market regulations, statechurch relations, etc., [for example, Alba and Holdaway (2009, 2013), Crul (2010), Crul and Schneider (2009), Holdaway et al. (2009), Sunier (2009)]. Research on the role of educational systems has been prompted partly by major international studies of educational performance like the Programme of International Student Assessment (PISA), which showed that children of immigrants from similar backgrounds had quite different outcomes in different countries (PISA 2006, 2001). Because the greatest challenge for education systems is integrating children of low-skilled labor migrants, assessing their relative success or failure in this task has been a focus of some of this comparative research, with Latinos the group of major concern in the United States (Alba and Holdaway 2009; Holdaway et al. 2009; Alba and Holdaway 2013).

The education of the children of rural-urban migrants in China has been attracting growing attention in recent years. Until the early 2000s, residence registration 
(hukou) and other policies prevented most migrants from settling in cities, and so their children generally remained in the countryside. Many studies of the children of migrants have focused on the educational attainment and psychological wellbeing of these "left behind children" (liushou ertong) [for example, Duan and Zhou (2005), Lu (2012), Murphy (2014), Ye (2008), Zhou et al. (2014, 2015)]. With the relaxation of controls on movement and policy shift to the active promotion of urbanization in the early 2000s, family migration increased and more migrant workers began to take their children with them to the city (Connelly et al. 2011). Researchers then turned their attention to these children and started to compare the educational outcomes and psychological wellbeing of children who migrated with their parents and those who remained in rural schools (Lai et al. 2014; Shen 2017; Wang et al. 2017), as well as the different standards of educational provision in different types of urban elementary schools, and migrant students' access to non-compulsory high school and postsecondary education [Chen and Feng 2013; Goodburn 2009; Han 2010, 2012; Han et al. 2017; Lan 2014; Lu and Zhou 2013; Xiong 2015. See also Pan (2017) for a review of research in Chinese]. Although there has been no detailed comparison of the educational experiences of migrant children in China and the US, some studies on China reference the US and European literatures, and have adapted the conceptual frameworks of "segmented" assimilation (Lu and Zhou 2013) and incorporation (Lan 2014) in their analysis of educational outcomes and their drivers. ${ }^{4}$

\section{Educational challenges for children of migrants: family resources}

So how similar are the circumstances of children of Latino migrants in the US and those of rural-urban migrants in China and to what extent do they face similar challenges in school? Although their parents are often more educated than the average in the sending country (Feliciano 2005), Latino immigrants usually have lower than average levels of education compared with the native born and are concentrated in low-paid jobs, often in the informal economy. In 2014, 54\% of Latino children in the US lived in families that were classified as low income, and only $74 \%$ of them had parents who had completed high school, compared with $94 \%$ of children of native born parents (Woods and Hanson 2016). Many Latino immigrants have limited English language skills and have difficulty communicating with teachers and school administrators; $23 \%$ of Latino children spoke a language other than English at home (Wood and Hanson 2016). Their parents often work long hours, leaving no time to supervise their children's studies, and if their work requires frequent moves, as in the case of farm workers, their children's education may also be disrupted by numerous changes of school. Migrant children often live in cramped conditions with nowhere quiet to study and may also have to help their parents with work or caring for younger siblings (Alba and Holdaway 2009; Holdaway et al. 2009; Kasinitz et al.

\footnotetext{
4 There is also a substantial literature on general disparities in educational provision between rural and urban areas and the implications for social mobility, economic growth and social justice, but due to constraints on space, this will not be discussed here.
} 
2008). Their concentration in the informal economy means that many do not have private health insurance and their legal status often excludes them from access to all but emergency care in the public sector (see Tran and Donato 2018). Children who are, or whose parents are, unauthorized ${ }^{5}$ are extremely insecure in their relationship with all public institutions, including schools. In 2012 an estimated 1.4\% of K-12 school children were unauthorized, and $6.9 \%$ had at least one unauthorized parent, with a high of $17.7 \%$ in California (Pew Research Center 2017). At the same time, research has almost universally found that migrant children and their parents have high levels of aspirations in terms of education (Kao and Tienda 1995), with many parents migrating partly in order that their children can enjoy better educational opportunities and pushing them hard to succeed (Louie 2004, 2012).

Internal migrants in China are in a quite similar social location. While they generally have higher levels of education (and post-migration income) than their peers in the countryside, migrant workers are disadvantaged in both respects compared to urban residents ( $\mathrm{Li} 2010)$. The majority (60\% in 2016) have a middle school education, compared with high school for established urban residents, and they are concentrated in low-paid, labor intensive sectors of the economy, including manufacturing, construction, transportation, catering, housekeeping and other services. Although policy has sought to address these problems, in 2015, more than $60 \%$ of migrants still had no formal labor contract (National Bureau of Statistics 2016). Most cities have now introduced temporary residence permits and pathways for converting to an urban hukou, most low-skilled migrants do not meet the requirements of settled employment and housing, and while it is true that the marketization of the economy and the expansion of welfare provision has reduced the significance of the hukou (Zhang 2018) internal migrants in China continue to face many of the same problems of unequal access to services faced by international migrants in the US (Chan and Buckingham 2008; Roberts 1997; Solinger 1999; Wang 2018). In 2014 , only $16 \%$ of migrants were covered by urban social security schemes, $18 \%$ had health insurance, and $10 \%$ had unemployment insurance (National Bureau of Statistics 2015). High levels of mobility, residential segregation and poor housing conditions are also problems that they share with low-skilled migrants to the US (Han et al. 2017; Lan 2014; Pan 2017; Shen 2017). Although they speak Mandarin and so language is not a barrier to learning, migrant children are nonetheless seen as outsiders and socially excluded (Han 2012; Han et al. 2017), marked by their regional accents, dress, and behavior; which are viewed by urbanites as indications of low personal "quality" or suzhi. (Murphy 2004). However, as with international migrants, both parents and their children are eager that they should escape the lowwage and often grueling occupations of the first generation. Regardless of whether children migrate with their parents or remain in the countryside, they have high educational aspirations (Han 2012; Murphy 2014; Shen 2017), although there is

\footnotetext{
5 I have used this term in preference to undocumented or illegal for the same reasons as Tran and Donato (2018): to avoid the implication of criminality, and because many migrants in this category do have some documents issued by the US government.
} 
evidence that these decline over time as they become more aware of the low ceiling to their attainment (Han 2012; Xiong 2015).

We can see then, that the challenges facing migrant children in both contexts fall into two categories, those that are related to their financial and other family resources, including social and cultural capital, and those that are related to their legal status or that of their parents. With regard to the former, with the exception of language, the two groups of children are remarkably similar. In terms of legal status, the picture is more complicated. Immigration law and policy in the US has undergone many shifts under different administrations; states pass their own laws relating to immigrants; and federal immigration policy is also implemented differently in different states and cities [see Fraga and Wilcox (2018) and Tran and Donato (2018)]. This makes it difficult to generalize about the extent to which migrants' legal status affects their rights to social protection. The same is also true in China. Central government policy towards migrants has evolved over time, generally, but not always in the direction of greater openness. However, the formally centralized system of government also obscures significant differences in the local formulation and implementation of policies (Zheng 2007), including those regarding migrants (Han 2016; Wang 2018; Zhang 2018). These differences have been accentuated by fiscal decentralization, which makes local government responsible for paying the bulk of the cost of providing social services (Jin et al. 2005). In both countries it is probably more useful to regard migration status as a scale rather than as a dichotomy; a scale on which there is a rough correlation and a negative, mutually reinforcing interaction, between poverty and status-related exclusion. It is important to note also that, in both cases, children themselves may have rights, including the right to free compulsory education, but are nonetheless profoundly affected by their parents' migration status, which will determine the larger context of their lives and the various resources available within the family to support their schooling.

The massive, rapid influx of children of low-skilled labor migrants therefore presents a similar challenge for educational systems in both China and the United States. The following section turns to the institutional context and considers how children of migrants have fared in the school systems of the two countries.

\section{Educational provision and Outcomes for children of migrants in the US}

The US educational system is a complex institutional landscape that offers extremely uneven opportunities to students from different backgrounds. This is largely because unlike centralized systems, education policy is mostly set and funded at the state and local level. The federal government contributes less than $10 \%$ of all educational expenditures. School districts are funded mostly by local property taxes and have considerable control over curriculum, with the result that their resources and the content of teaching strongly reflect community financial capacity and cultural norms and often exacerbate underlying inequalities (Hochschild and Scovronick 2003, Kozol 1991; US Commission on Civil Rights 2018; US Department of Education 2013). 
Primary education has been compulsory in all states since 1918 and compulsory schooling now ends at age 16-18, depending on the state. Children of migrant parents who are born in the US are citizens, and automatically entitled to receive free education in public schools, as are children whose parents hold valid visas. However, universal access to public schools did not always explicitly include unauthorized children. In 1975, the Texas State legislature passed a ruling that school districts could refuse to enroll students who were unauthorized and some schools began to charge a $\$ 1000$ fee to students who could not prove their legal status. These practices were ruled unconstitutional in a Supreme Court judgment, Plyler vs. Doe, in 1982 for violating the 14th Amendment regarding equal protection of the law. Some states have attempted to resist this ruling. In 1994, California passed proposition 187, which made it illegal for unauthorized students to attend public schools, but it was overturned in federal court as unconstitutional. Since this time, then, all children have been guaranteed the right to compulsory education through the end of high school, regardless of migration status.

While some other countries have introduced policies to support immigrant students in elementary and secondary education - the Netherlands, for example, provides additional per capita funding for immigrant students-American schools have not provided support on the basis of immigrant origin. Since 1974 federal funds have been allocated to provide bilingual and English as a Second Language education, although the way in which these have been used has been very different in different states and, as with the admission of unauthorized students, some states have attempted to defy the federal ruling. Children of immigrants from poor families also benefit from the 1965 Elementary and Secondary Education Act (ESEA) which provides federal funding to support school districts with concentrated poverty (known as Title 1 schools) (Alba and Holdaway 2013; Crul and Holdaway 2009).

With elementary and secondary education, then, immigrant status is not an issue in terms of access to schooling, although as discussed further below, it is relevant to the quality of the education children receive. When it comes to post-secondary education, legal status becomes crucial, as when they reach the age of 18, unauthorized students are potentially subject to deportation. The vast majority of children of immigrants in the United States are citizens, but the fate of 800,000 "Dreamers," unauthorized young adults who have since 2012 been permitted to stay in the United States as long as they were enrolled in college or the military, now hangs in the balance under the Trump administration (Guardian (2017). More relevant for most children of immigrants is the cumulative impact of their poor quality previous education, which stands them in poor stead when it comes to college admission and retention. The cost of education also becomes a significant factor. According to the College Board, in 2016-2017, average fees for in-state students in public institutions were $\$ 3520$ per year in 2-year colleges and $\$ 9650$ in 4-year colleges, while the average at not-for profit universities was $\$ 33,480$. Living costs added $\$ 10-12,000$ per year. Although up to $70 \%$ of students receive some financial aid, these costs are still a significant barrier for low-income immigrant families (College Board 2016).

In terms of educational outcomes, comparative research on educational outcomes of children of immigrants in the United States and Europe has found that some students from immigrant origin families do remarkably well, and most exceed their 
parents' level of education. But at the same time, the majority is disadvantaged on average when compared with children from native families, and the magnitude of the immigrant-native gap is similar across systems with very different structures and features. The gap is clearest at the lower end of the educational spectrum. One study that compared outcomes in the US, France, the Netherlands, and the UK found that with the exception of the UK the advantage for children from native families was almost two-to-one (Alba and Holdaway 2013:13), and in the case of Mexican-American versus Anglo youth in the US it was even higher, with 16\% of Mexican girls and $20.5 \%$ of boys leaving high school without a diploma, compared with only 5.8 and $8 \%$ of white youth (Alba et al. 2013:166). In some urban schools the dropout rate for Latino students is more than 50\% (Orfield and Lee 2007).

When it comes to higher education, there is also a substantial advantage for young people from native families. Comparing children of Mexican immigrants with the native born, the advantage is again roughly two-to-one in terms of university credentials. Even among those who do attend college, there are clear differences in institutional quality, with children of working class immigrants concentrated in two-year community colleges and less selective 4-year post-secondary institutions and very under-represented in post-graduate and professional programs (Alba and Holdaway 2013; Alba et al. 2013; Kasinitz et al. 2008). A similar pattern is evident in the UK, even though children of immigrants attend university in larger numbers (Waters et al. 2013). Comparison of countries that have more and less open access to university suggests that where lower level credentials are more universally attainable, the locus of competition shifts up the system. The effect of this is likely that more open systems enable larger number of children of immigrants to enter paraprofessional and "pink collar" occupations, but exclude them from highly paid professions, while more selective systems leave a greater number of children of immigrants in blue collar and service industries but enable a small number to enter elite occupations (Alba and Holdaway 2013; Schnell et al. 2013).

Research in the US and Europe has shown that educational policies and institutional arrangements are important in shaping the educational attainment of children of immigrants. Many factors interact, and negative and positive conditions coexist in many systems; crucial turning points in the educational pipeline also differ. Research has pointed to the length of the school day and year; class size; tracking mechanisms; and the division of labor between schools and families as important factors (Alba and Holdaway 2013; Holdaway et al. 2009; Alba and Holdaway 2009) In the United States, unequal educational funding and resources, underpinned by racial and ethnic segregation, have been identified as major contributors to the inequality of outcomes. The ruling of the Supreme Court in Brown vs Board of Education in 1954 upheld the right of black children to attend white schools, and declared that "education is a right that must be made available to all on equal terms," again on the basis of the 14th Amendment, but segregation has persisted nonetheless and worsened in recent years, with negative impacts on the educational opportunities of Latino as well as black students (Logan et al. 2008; Orfield 2001; Orfield and Lee 2007). In fact, Latino students have been found to be the most disadvantaged, with about $40 \%$ in "intensely segregated schools" where they often experience "triple segregation" of race, class and language (Orfield and Lee 2007). In 2005-2006, 
$20 \%$ of US schools reported having at least $70 \%$ black and Latino students, and more than $80 \%$ of these schools reported that at least half their students qualified for free or reduced-price lunches, an indicator of family poverty (Orfield and Lee 2007).

In addition to having high concentrations of students who are poor and who often have multiple, complex needs for educational and social support, these urban schools are generally under-resourced and offer limited educational opportunities. The dependence of schools on local property taxes for funding means that there are significant differences both across and within states, and across urban and suburban school districts, often of a magnitude of one to two or three times. A 2018 report by the United States Commission on Civil Rights found that funding per child varied from a high of $\$ 20,251$ in New York to a low of \$6546 in Utah. Despite lawsuits requiring states to reduce inequality, and Title 1 federal funding, within state differences in per child spending are also still extremely large. For example, per pupil spending in the urban District of Philadelphia, which serves mostly poor, minority students, was $\$ 13,000$, compared with $\$ 23,000$ in a suburban district serving mostly white students; and per pupil spending in the state of Pennsylvania as a whole ranged from $\$ 8700$ to $\$ 26,600$ (US Commission on Civil Rights 2018). Lower funding translates into larger classes, poorer facilities and less experienced teachers, as well as the lack of calculus and other advanced courses necessary for college preparation (US Commission on Civil Rights 2018). The bi-partisan Equity and Excellence Commission concluded in 2013 that,

Admittedly, many of these disadvantaged students enter school far behind their more advantaged peers. But instead of getting deadly serious about remedying that fact-by making sure such students are in high-quality early childhood and pre-K programs, attend schools staffed with teachers and leaders who have the skills and knowledge to help each student reach high standards, get afterschool counseling or tutorial assistance or the eyeglasses they need to see the smart board-the current American system exacerbates the problem by giving these children less of everything that makes a difference in education (US Department of Education 2013).

Stark differences in student outcomes appear as early as elementary school, with sizeable achievement gaps between Latino and White students (Reardon et al. 2017). Although the United States does not have a formal system of tracking students into schools that are designated as academic or vocationally oriented, disparities in the quality of early education function as a powerful informal tracking mechanism that disadvantages not only native born black children but also many children of immigrants (Crul and Holdaway 2009; Kasinitz et al. 2008; Oakes 2005). Many Latino students go on from weak elementary and middle schools to be over-represented in the worst-resourced high schools, sometimes described as "dropout factories" (Orfield and Lee 2007): one study of second generation youth in New York found that $60 \%$ of Dominican students were concentrated in high schools in two lowest quintiles in terms of academic performance (Kasinitz et al. 2008). Given this, it is not surprising that these students graduate at lower rates or that those who manage to attend college are concentrated in the vocationally-oriented community college 
system and in lower ranking four-year universities, with higher attrition rates than the children of native born whites.

Certain recommendations regarding support for children of immigrants have been distilled from comparative research in Europe and the United States. These include increasing contact hours through pre-school programs, and longer school days and years, in order to address the time constraints on immigrant parents and their limited knowledge of English; reducing inequalities between schools by equalizing funding; reducing class sizes and improving teacher quality; providing supplemental educational services including after school, summer and mentoring programs; targeted support for migrant students at decisive points in the educational pipeline and counseling about educational options and related needs for preparation; flexible tracking and opportunities to re-enter education; scaffolding the transition from school to work through internships and apprenticeships; financial assistance for post-secondary education; and strengthening ties between the school and the community to enable migrant parents to play a more active role in school governance (Alba and Holdaway 2013).

Some such programs, in particular mentoring schemes and supplementary funding to support additional teachers and teachers' aides, have been implemented with some success in the Netherlands (Crul 2002; Crul and Holdaway 2009; Heckmann 2008). However, it is noticeable that unless they also derive some benefit from these programs, native born parents will often deploy "reactive" strategies to protect the educational advantages enjoyed by their children, moving to school districts with fewer immigrant children, putting their children in private or religious schools or providing supplemental after school education (Alba and Holdaway 2013) and thereby ensuring a kind of "maximally maintained inequality" (Lucas 2001). More fundamentally, inequality in schools is underpinned by race and ethnic residential segregation, which makes it difficult for education policy in isolation to resolve it (Mordechay and Orfield 2017; Orfield and Lee 2007; US Commission on Civil Rights 2018).

\section{Educational provision and outcomes of children of internal migrants in China}

Until recently, children of rural-urban migrants in China were arguably even more disadvantaged than children of international migrants in many developed countries in terms of their access to educational opportunities. When the problem of migrant children's education first came to attention in the 1990s, the government's initial policy was to insist, on the basis of the hukou policy, that migrants' children be educated in rural areas and only in unusual circumstances to allow parents to apply for their children to study [literally "borrow study" (jiedu)] at urban schools, paying fees for the privilege. As a result, most children of migrants remained in rural areas, and inexpensive, privately run schools sprang up to meet the demand of those who accompanied their parents to the city. At this time, the family's hukou status played a decisive role in determining educational opportunities (Han 2010; Goodburn 2009).

The 2001 State Council Decision on Basic Education Reform and Development and the 2006 Compulsory Education Law changed this principle by stipulating that 
local governments should be responsible for providing compulsory education to all children and that children should attend schools close to their home (jiujin ruxue), policies which came to be referred to as "the two main points." (liangge weizhu). Subsequent directives instructed that schools in destination cities should make provision for migrant students and reduce or eliminate discriminatory fees. However, in fact many obstacles remain. First and foremost, the central government policy demand for urban schools to admit migrant children did not come with money attached, meaning that municipalities, and districts within them, had to pick up the bill for absorbing rapidly growing number of migrant students without assistance from higher levels of government. Although declining numbers of local students should have eased this burden, the misfit between the location of existing schools and concentrations of migrants meant that school places and applicants often did not coincide, and additional schools and teachers were needed in new locations which were not included in the planning process or hiring quotas (Han 2012; Zhou and Wang 2016; Wang 2018).

The situation is complicated by the fact that as with many other policies towards migrants, cities can design their own detailed regulations, "interpreting" (jiedu) and "adapting" (biantong) national mandates in accordance with their own interests (Wang 2018). Many of these local regulations serve to exclude migrant children. In Beijing, the Comments on Student Admission to Compulsory Education in 2014 issued by Beijing Municipal Commission for Education specified that migrant parents seeking to enroll their children in public school had to produce "five certificates": temporary residence permits for both parents, a certificate of "no guardianship" in the location they came from, household registration documents for both student and parents, and employment permits and apartment leases in the district. Districts within the municipality can add further requirements. For example, Chaoyang and Tongzhou districts of Beijing require that both parents work formally in that district and pay social insurance there for more than 1 year, that they have property ownership certificates or formal apartment leases in the district, and that the certificate of no guardianship in the sending place be signed by the local Public Security Bureau ( $\mathrm{Li}$ et al. 2017). It is hard for many migrants to obtain these documents, as they often work in the informal economy with no labor contract and rent rooms without a formal lease. These regulations are therefore creating stratification within the migrant population by restricting educational opportunity for the children of the most disadvantaged (Han et al. 2017; Wang et al. 2017).

There has been progress, at least in terms of access to elementary education in urban areas. More migrant students are attending either public schools or semi-public schools (minban xuexiao) that are government regulated and funded, with a different mix of public and private provision in different cities. (See Han (2016) and Wang (2018) for a discussion of the different municipal approaches and the reasons for them.) By the end of 2014, $80 \%$ of migrant students nationally were attending public schools, and the government had bought out more than 1.2 million migrant schools (Lu and Chu 2017). However, there is a clear and descending hierarchy in terms of the quality of education in different schools in terms of funding, facilities and teaching quality, from elite public schools, through ordinary public schools, to semi-public schools and finally private migrant schools that are completely outside 
the public system. Within both the public and private systems, migrants are concentrated in less well-resourced schools (Han et al. 2017; Lu and Chu 2017; Li et al. 2017; Zhou and Wang 2016). For example, in 2008 Shanghai merged 35 migrant schools in District Five into 13 semi-public institutions (minban xuexiao) with funding from district resources and using the local curriculum. It also progressively expanded the enrollment of migrant children in District Five's public schools. By 2012 about $57.8 \%$ of migrant students in the district were enrolled in public schools, which saw annual growth of $7.8 \%$ from 2008 to 2012, compared with $4 \%$ for the city as a whole (Zhou and Wang 2016). Educational expenditure for the district grew by about $10.7 \%$ a year from 2008 to 2012, reaching four billion yuan in 2013, of which one billion yuan came from the municipal level and three billion from the district. But minban schools were funded at 5000 yuan per pupil per year, while average public school expenditure per student was 17,000. Public school teachers were also more qualified and experienced, with far higher salaries than those of minban school teachers (Zhou and Wang 2016). Furthermore, within the public sector, migrant children are concentrated in lower ranking schools in peripheral areas (Zhou and Wang 2016; Li and Placier 2015; Lan 2014), and even when they attend the same school, migrant students are sometimes kept separate from children of local families in classes and in the playground (Lan 2014).

Researchers have compared educational outcomes for children of migrants in primary school with those of their counterparts with migrant and non-migrant parents who remain in rural areas and with non-migrant students in urban schools. They have also looked at educational performance of migrant children in different types of urban schools. Chen and Feng (2013) found that migrant elementary students in Shanghai attending public schools did better than those in private schools in both language and mathematics, with a much smaller gap with local students, while students in private migrant schools had the weakest performance. Other studies have had similar findings (Lu and Zhou 2013; Han et al. 2017). The poor level of education, especially in private migrant schools, has led some researchers to ask whether the children of migrants might not be better off being "left behind" (Wang et al. 2017; Lai et al. 2014). Wang et al. (2017) found that 5th grade migrant students from Anhui who attended private migrant schools in Shanghai and Suzhou performed worse than students in public rural schools back in the sending communities. Although migrant schools had better facilities, were newer and had smaller class sizes, this was offset by the fact that rural school teachers were all formally qualified and had more years of teaching experience. This reflects the greater state investment in rural education in recent years, although rural public schools still lag far behind urban schools in terms of both educational provision and results due to decades of urban bias (Han et al. 2017; Wang et al. 2017; Xiang 2007).

A particular characteristic of the Chinese education system, and one that is especially damaging to the opportunities of children of migrants, is the way in which the transition to higher non-compulsory and post-secondary education is structured. Students must take a test to enter high school (the zhongkao) and another for university entrance (the gaokao). Until recently, these tests were open only to students with local residence registration and migrant children who wanted to continue their education had to return to their province of origin after middle school. Because children 
applying from outside the province must score higher on the test than local children, very few children of migrants are able to test their way back to university in the firsttier cities (Han 2010, 2012; Lan 2014; Lu and Chu 2017; Mok et al. 2011). Because the content of the high school curriculum and the gaokao test are different in different provinces, the decision about where to study must be made at the end of middle school (Han 2012; Xiang 2007).

In 2012, the central government required cities to develop policies for relaxing restrictions on access to post-compulsory education for migrant children and by August 201427 provinces had introduced policies for relaxing restrictions on the zhongkao and 30 had done so for the gaokao (Lu and Chu 2017). However, most cities still impose strict requirements regarding settled work, housing and social insurance participation that exclude the majority of migrant parents from entering their children for these exams [see Wang (2018) for a detailed discussion]. One study that followed up on implementation of these policies found "no effective relaxation" of restrictions on the gaokao in top tier cities like Beijing, Tianjin, Shanghai and Guangzhou and only limited relaxation in middle-ranking provinces ( $\mathrm{Lu}$ and Chu 2017) Many cities also limit the types of high school that migrant students can apply to, reserving elite, academically-oriented schools for local students. As a result, although some migrant children are now able to pursue vocational education in urban areas, for the vast majority, unless they can test back in as rural students, university continues to be an unattainable goal and they are effectively excluded from professional occupations (Han 2012; Lan 2014; Mok et al. 2011). Of course, the right to access higher education is not the only issue. For poor rural and migrant families, the costs of high school and university are exorbitantly high and the opportunity costs of lost wages must also be considered (Li et al. 2017).

Overall, most researchers therefore conclude that although there has been progress in terms of access to primary education for the children of migrants who accompany their parents to the city, in terms of quality, the educational system is largely serving to maintain inequality, particularly in terms of preparation for and access to post-secondary education. The combination of inferior primary education and exclusion from academic urban secondary schools denies migrant children the opportunity to realize their potential and pushes them either directly into the labor market or at best into vocational programs (Han 2012, 2016; Han et al. 2017).

The obstacles to better educational provision for migrant students in China despite the formal commitment to integrate them are quite similar to those operating in the United States. School financing arrangements place the dominant burden on local government and the relationship between capacity and needs is not considered (Li et al. 2017; Mok et al. 2011; Zhou and Wang 2016). Inflexible teacher staffing policies impose quotas for hiring that are not easily transferable as urban school populations grow, sometimes extremely rapidly; and land use policies make allocating land for school buildings difficult. As in the United States, residential segregation concentrates inequalities and makes it hard to equalize the quality of educational provision: migrants increasingly tend to be concentrated in suburban and peripheral areas where there are few existing schools and none with a good academic reputation (Han 2012; Zhou and Wang 2016). Meanwhile, local parents seek to retain their privileged access to the limited number of places in elite schools and universities 
by resisting reform of the gaokao system that advantages local students and providing supplemental education outside school (Han et al. 2017; Mok et al. 2011). Noting the crucial role of education in poverty alleviation, economic growth and social mobility, researchers have called for fiscal transfers from the central government to improve the quality of education in schools attended by migrants, for expansion of the quota for high school admissions to reflect the total and not only the registered urban population, for the continued relaxation of restrictive admissions policies based on residence registration and the introduction of a unified gaokao. However, many of these reforms will require strong action at the national level. (Han et al. 2017; Li et al. 2017; Lu and Chu 2017).

\section{Reflections}

Research in the US and Europe has found that most educational systems provide some opportunities for social mobility for children of migrants, including those from disadvantaged backgrounds. At the same time, they curtail opportunities for the majority, reproducing broad patterns of inequality. Similar trends seem to be emerging in terms of the education of the children of rural-urban migrants in China. In all cases, there is some disagreement among researchers and policymakers over whether the glass is half full or half empty, which often hinges upon whether the focus is on mobility in relation to the parental generation or on the gap between migrant children and those from native born/urban families, These debates raise the questions of what the minimum level of educational attainment is that children require as "the essential prerequisite(s) for adult participation in society" (Fishkin 1997); how much mobility can reasonably be expected over one generation; and how much inequality in outcomes is tolerable.

The answers to these questions are likely to vary across societies and the upper bound of what level of education is considered necessary is certainly open to dispute: for example, there is considerable disagreement over the issue of whether "college for all" is a feasible or even desirable goal (Rosenbaum 2001). Success also brings its own headaches. High rates of educational failure generate criticism of educational institutions and the stigmatization of migrants. But on the other hand, elites are none too pleased when children of migrants begin to outperform their own offspring and threaten their privileged access to prestigious institutions, as is the case with children of Chinese and Indian immigrants in the United States. However, given that completing secondary education is more or less a prerequisite for employment in modern economies, the failure of many second-generation immigrants in the US to complete high school is almost universally regarded as unacceptable.

Although the expansion of educational opportunity may merely raise the floor and displace the locus of competition to higher reaches of the system, ensuring that all students complete compulsory schooling and leveling the playing field in terms of access to post-secondary education nonetheless has meaningful consequences in terms of improving the life circumstances of many individuals and their families. Historical examples of such successful expansion in the United States are the GI Bill, which enabled large numbers of working class men to enter college in the 
years following the Second World War, and the Open Admissions policy of the New York City University system in the 1960s, which led to the enrollment of large numbers of immigrant and minority students. This substantially increased students' own incomes and led to higher rates of college attendance among their children (Attewell and Lavin 2007).

Are China and the US entering another period in which this kind of qualitative change is possible? Certainly, both countries are experiencing profound demographic transitions in which native born/urban populations are ageing and children of migrants make up a growing percentage of students and young workers. Richard Alba has argued in Blurring the Color Line (2009) that the retirement of the baby boom generation and low birthrates among native born whites in the US might provide the incentive to draw larger numbers of immigrant and minority background youth into higher levels of education. Clearly, doing so will be crucial for maintaining the nation's economic competitiveness: in all but one of the nation's 10 largest and most productive metropolitan areas, which together contribute more to the nation's economy than 46 other states combined, the majority of children aged 0-5 are already from minority backgrounds, with Latinos the largest group (Mordechay and Orfield 2017). Yet recent developments are not encouraging. One recent assessment of the situation concludes that although a few cities have attempted to tackle the roots of segregated and unequal schooling through innovative housing and education policies, overall, there is a "policy vacuum" in terms of efforts to provide more equal access to high quality education (Mordechay and Orfield 2017). The reports of the Equity and Excellence Commission (2013) and the US Commission on Civil Rights (2018) are equally discouraging.

In China, different but equally important transitions are taking place. The whole population is ageing, but because birth control policies were implemented most strictly in cities, urban populations that have dominated the higher levels of education and the labor market are ageing faster than those in rural areas. As urbanization proceeds, the school age and young working population will increasingly be dominated by children of migrants and rural residents. As China's equivalent of the baby boomers (the pre-population control generation) moves out of the labor force, opportunities should open up for migrants and their children who have the education to fill them. China is also attempting to upgrade its development model, increase worker productivity and avoid the "middle income trap" (Cai 2012) by moving away from reliance on low-cost manufacturing towards higher value services and industries that require a more educated workforce. Researchers have argued that this combination of demographic and economic pressures calls for policies to ensure better educational opportunities for the children of migrants and rural people (Khor et al. 2016; Li et al. 2017) but it remains to be seen if this advice will be heeded.

Juxtaposing the US and China together has revealed some telling similarities that transcend the apparent differences in contexts. In both cases, children of labor migrants face challenges in their education that relate to their migration status and that of their parents. Even if their own access to education in the receiving place is ensured, as it is now for the duration of compulsory education in both countries, their parents' exclusion from many of the benefits of citizenship by virtue of their legal status continues to leave them disadvantaged and insecure in comparison with 
young people of native born/urban parents. At the same time, both the US case and the emerging situation in China show that while the right to access education is essential, it is not sufficient; ensuring high quality education for all children is also crucial if they are to be successfully integrated. Children of migrants face the challenge of not just reproducing but exceeding their parents' level of educational attainment in the context of constrained family financial and social resources. While education policy cannot make these underlying social inequalities go away, it should not compound them by tolerating a situation in which children of migrants also receive inferior schooling. Figuring out how to target public investment in ways that can most effectively level the playing field should be an urgent focus of research and policy.

Open Access This article is distributed under the terms of the Creative Commons Attribution 4.0 International License (http://creativecommons.org/licenses/by/4.0/), which permits unrestricted use, distribution, and reproduction in any medium, provided you give appropriate credit to the original author(s) and the source, provide a link to the Creative Commons license, and indicate if changes were made.

\section{References}

Alba, R. (2009). Blurring the color line: The new chance for a more integrated America. Cambridge: Harvard University Press.

Alba, R., \& Holdaway, J. (Eds.). (2009). Immigrant Communities and American Schools. Special issue, Teachers College Record, vol. 111(3), pp. 597-615.

Alba, R., \& Holdaway, J. (Eds.). (2013). The Children of Immigrants in Schools: A Comparative Look at Integration in the US and Western Europe. New York: New York University Press.

Alba, R., Silberman, R., Abdelhady, D., Brinbaum, Y. and Lutz, A. (2013). How similar educational inequalities are constructed in two systems, France and the United States: Why they lead to disparate labor market outcomes. In Alba and Holdaway (Eds.), Children of Immigrants in Schools.

Attewell, P., \& Lavin, D. (2007). Passing the torch: Does higher education for the disadvantaged pay off across the generations?. New York: Russell Sage Foundation.

Bureau of Labor Statistics. (2017). Unemployment rates and earnings by educational attainment, 2016. https://www.bls.gov/emp/ep_chart_001.htm. Accessed 4 Oct 2016

Cai, F. (2012). Is there a middle income trap? Theories, experiences and relevance to China. China and World Economy, 20(1), 49-61.

Carling, J., Menjívar, C., \& Schmalzbauer, L. (2012). Central themes in the study of transnational parenthood. Journal of Ethnic and Migration Studies, 38(2), 191-217.

Castles, S., \& Miller, M. (2003). The age of migration: International population movements in the modern world (3rd ed.). Basingstoke: Palgrave-Macmillan.

Chan, K. W., \& Buckingham, W. (2008). Is China abolishing the Hukou system? The China Quarterly, 195, 582-606.

Chen, Y., \& Feng, S. (2013). Access to public schools and the education of migrant children in China. China Economic Review, 26, 75-88.

College Board. (2016). Trends in College Pricing. https://trends.collegeboard.org/sites/default/files/2016trends-college-pricing-web_1.pdf. Accessed 18 Mar 2018.

Connelly, R., Roberts, K., \& Zheng, Z. (2011). The settlement of rural migrants in urban China-some of China's migrants are not 'floating' anymore. Journal of Chinese Economic and Business Studies, 9(3), 283-300.

Crul, M. (2002). Success Breeds Success. Moroccan and Turkish Student Mentors in the Netherlands. International Journal for the Advancement of Counselling, 24(4), 275-287. 
Crul, M. (2010). How do educational systems integrate? Integration of second-generation Turks in four different institutional settings. In R. Alba \& M. Waters (Eds.), The new dimensions of diversity: the children of immigrants in North America and Western Europe. New York: New York University Press.

Crul, M., \& Holdaway, J. (2009). Children of immigrants in school in New York and Amsterdam: the factors shaping attainment. Teachers College Record, 111, 1476-1507.

Crul, M., \& Schneider, J. (2009). Integration of Turkish second-generation men and women in Germany and the Netherlands: The impact of differences in vocational and academic tracking systems. Teachers College Record, 111, 1508-1527.

Crul, M., \& Vermeulen, H. (2003). The second generation in Europe. International Migration Review, 37, 965-986.

Department of Service and Management of Migrant Population, National Health and Family Planning. Commission. (2017). Report on China's Migrant Population Development 2016 (pp. 3-6). Beijing: China Population Publishing House.

DeWind, J., \& Holdaway, J. (2008). A framework for linking and comparing the development impacts of internal and international migration in research and policy. In Josh DeWind \& Jennifer Holdaway (Eds.), Migration and development within and across borders. Geneva: International Organization for Migration.

Duan, C., \& Zhou, F. (2005). A study of the situation of left-behind children in rural China. Population Research, 1. (In Chinese).

Favell, A. (2001). Philosophy of integration: immigration and the idea of citizenship in France and Britain. London: Palgrave.

Feliciano, C. (2005). Educational selectivity in US immigration: How do immigrants compare to those left behind? Demography, 42(1), 131-152.

Fishkin, J. (1997). Liberty versus equal opportunity. In L. P. Pojman \& R. Westmoreland (Eds.), Equality: Selected readings. New York: Oxford University Press.

Fraga, L.R., \& Wilcox, B.J. (2018). Comparative social rights: Status and integration in the United States. China Population and Development Studies, 1

Freeman, G. (2004). Immigrant incorporation in western democracies. International Migration Review, $38,945-969$.

Gans, H. (1992). Second generation decline: Scenarios for the economic and ethnic futures of the post1965 American immigrants. Ethnic and Racial Studies, 15(2), 173-192.

Gibson, M. (1988). Accommodation without assimilation: Sikh immigrants in an American high school. Ithaca: Cornell University Press.

Goodburn, C. (2009). Learning from migrant education: a case study of the schooling of rural migrant children in Beijing. International Journal of Educational Development, 29(5), 495-504.

Guardian. (2017). What is Daca and who are the Dreamers?. https://www.theguardian.com/us-news/2017/ sep/04/donald-trump-what-is-daca-dreamers. Accessed 14 Sept

Han, J (2010). Education for Migrant Children. Background paper prepared for the Education for All Global Monitoring Report. Reaching the Marginalized. 2010/ED/EFA/MRT/PI/42. http://unesd oc.unesco.org/images/0018/001865/186590e.pdf

Han, J. (2012). Rapid urbanization and the aspiration and challenge of second-generation urban-rural migrants. Chinese Education \& Society, 45(1), 77-83.

Han, J. (2016). Similar policies, different practices: comparative research on policies for compulsory education of migrant children in Beijing, Shanghai and Guangzhou (1996-2013). In Zheng et al., (Eds), Comparative Research on Migration in China and the United States.

Han, J., Gao, Y., Zhang, Y., \& Han, C. (2017). Urban-rural extension: Urban-rural reproduction among different groups of children. Chinese Education \& Society, 50(4), 315-335.

Heckmann, F. (2008). Education and migration: Strategies for the successful integration of migrant children in European schools and societies. Bamberg: European Forum for Migration Studies.

Hochschild, J., \& Scovronick, Nathan. (2003). The American dream and the public schools. New York: Oxford University Press.

Holdaway J, Crul, M., \& Roberts, C. (2009). Cross-National comparison of provision and outcomes for the education of the second generation. In Jennifer Holdaway, Maurice Crul and Catrin Roberts, (Eds.), Educating Immigrant Youth: Pathways to Mobility and Citizenship in International Perspective. Special issue, Teachers College Record, vol. 111(6), pp. 1381-1403.

Jin, H., Qian, Y., \& Weingast, B. (2005). Regional decentralization and fiscal incentives: Federalism, Chinese style. Journal of Public Economics, 89(9-10), 1719-1742. 
Kao, G., \& Tienda, M. (1995). Optimism and achievement: The educational performance of immigrant youth. Social Science Quarterly, 76, 1-19.

Kasinitz, P., Mollenkopf, J., Waters, M., \& Holdaway, J. (2008). Inheriting the city: the children of immigrants come of age. Cambridge: Harvard University Press/Russell Sage Foundation.

Khor, N., Pang, L., Liu, C., Chang, F., Mo, D., Loyalka, P., et al. (2016). China's looming human capital crisis: Upper secondary educational attainment rates and the middle income trap. China Quarterly, 228, 905-926.

Kozol, J. (1991). Savage inequalities: Children in America's schools. New York: Crown.

Lai, F., Liu, C., Luo, R., Zhang, L., Ma, X., Bai, Y., et al. (2014). The education of China's migrant children: The missing link in China's education system. International Journal of Educational Development, 37(1), 68-77.

Lan, P. (2014). Segmented incorporation: the second generation of rural migrants in urban China. The China Quarterly, 216, 1-23.

$\mathrm{Li}$, S. (2010). The economic situation of migrant workers in China. China Perspectives, 4, 4-15.

Li, N., \& Placier, P. (2015). Migrant and non-migrant families in Chengdu, China: Segregated lives, segregated schools. Social Sciences, 4, 339-360.

Li, H., Loyalka, P., Rozelle, S., \& Wu, B. (2017). Human capital and china's future growth. Journal of Economic Perspectives, 31(1), 25-48.

Logan, J., Oakley, D., \& Stowell, S. (2008). School segregation in metropolitan regions: the implications of policy choices on public education. American Journal of Sociology, 113, 1611-1644.

Louie, V. (2004). Compelled to excel: Immigration, education, and opportunity among Chinese Americans. Palo Alto: Stanford University Press.

Louie, V. (2012). Keeping the immigrant bargain: The costs and rewards of success in America. New York: Russell Sage Foundation.

Lu, Y. (2012). Education of children left behind in rural China. Journal of Marriage and Family, 74, 328-341.

Lu, W., \& Chu, H. (2017). Reform of education for children who migrate with their parents from the perspective of poverty relief: How to realize equal opportunities to school admissions and an equal start in education. Educational Management Research, July. pp. 57-62. (In Chinese).

Lu, Y., \& Zhou, H. (2013). Academic achievement and loneliness of migrant children in China: School segregation and segmented assimilation. Comparative Education Review, 57(1), 85-116.

Lucas, S. (2001). Effectively maintained inequality: Education transitions, track mobility and social background effects. American Journal of Sociology, 106, 1642-1690.

Mok, K., Wong, H., \& Guo, Y. (2011). Transforming from economic power to soft power; challenges for managing education for migrant workers' children and human capital in Chinese Cities. Asia Pacific Journal of Education, 31(3), 325-344.

Mordechay, K., \& Orfield, G. (2017). Demographic transformation in a policy vacuum: The changing face of US metropolitan society and challenges for public schools. The Educational Forum, 81(2), 193-203.

Murphy, R. (2002). How migrant labor is changing rural China. New York: Cambridge University Press.

Murphy, R. (2004). Turning peasants into modern Chinese citizens: "Population quality" discourse, demographic transition and primary education. The China Quarterly, 177, 1-20.

Murphy, R. (2014). School and study in the lives of in the lives of rural families: A view from rural Jiangxi. Development and Change, 45(1), 29-51.

National Bureau of Statistics (2015). National Monitoring Survey of Migrant Workers 2014. http://www. stats.gov.cn/tjsj/zxfb/201504/t20150429_797821.html. Accessed 29 April.

National Bureau of Statistics. (2016). National Monitoring Survey of Migrant Workers 2015. http://www. stats.gov.cn/tjsj/zxfb/201704/t20170428_1489334.html. Accessed 28 April.

Oakes, J. (2005). Keeping track: How schools structure equality. New Haven: Yale University Press.

Orfield, G. (2001). Schools more separate: Consequences of a decade of resegregation. UCLA. The Civil Rights Project. https://escholarship.org/uc/item/5cx838jx

Orfield, G., \& Lee C. (2005). Historical reversals, accelerating resegregation, and the need for new integration strategies. A report of the Civil Rights Project/Proyecto Derechos Civiles, UCLA August. https://www.civilrightsproject.ucla.edu/research/k-12-education/integration-and-diversity/historicreversals-accelerating-resegregation-and-the-need-for-new-integration-strategies-1/orfield-historicreversals-accelerating.pdf 
Pan, L. (2017). "China Dream" and the educational rights of mobile social groups. A literature review of research on the problem of education of children who accompany migrant workers to the City. Rural Economy and Technology, 28(7), 220-222. (In Chinese).

Parrenas, R. S. (2005). Children of global migration: Transnational families and gendered woes. Stanford: Stanford University Press.

Pew Research Center. (2017). Facts on Immigration. (Tabulations of 1960-2000 decennial censuses and 2010, 2013-2015 American Community Surveys (IPUMS)). May 3. http://www.pewhispani c.org/2017/05/03/facts-on-u-s-immigrants/\#fb-key-charts-origin.

Pieke, F., \& Mallee, H. (Eds.). (1999). Internal and international migration: Chinese perspectives. Surrey: Curzon.

PISA. (2001). Knowledge and skills for life: first results from the OECD programme for international student assessment (PISA) 2000. Paris: OECD.

PISA. (2006). Where immigrant students succeed-a comparative review of performance and engagement in PISA 2003. Paris: OECD.

Portes, A., \& Rumbaut, R. (2006). Immigrant America: A portrait (3rd ed.). Berkeley: University of California Press.

Portes, A., \& Zhou, M. (1993). The new second generation: Segmented assimilation and its variants. The ANNALS of the American Academy of Political and Social Science, 530(1), 74-96.

Reardon, S.F., Kalogrides, D., \& Shores, K. (2017). The Geography of Racial/Ethnic Test Score Gaps (CEPA Working Paper No.16-10). Retrieved from Stanford Center for Education Policy Analysis: http://cepa.stanford.edu/wp16-10

Roberts, K. (1997). “China's 'Tidal Wave' of migrant labor: What can we learn from Mexican Undocumented Migration to the United States?". International Migration Review, 31(2), 2490-2930. (Summer).

Rosenbaum, J. (2001). Beyond College for all: Career paths for the Forgotten half. New York: Russell Sage Foundation.

Rumbaut, R., \& Portes, P. (2001). Ethnicities: Children of immigrants in America. University of California Press: Russell Sage Foundation

Schnell, P., Keskiner, E., \& Crul, M. (2013). Success against the odds. Education Inquiry, 4(1), $125-147$.

Shen, Y. (2017). "Migrating" or being "Left Behind": The education dilemma of rural children in Mainland China. Chinese Education and Society, 50, 244-271.

Smith, R. C. (2006). Mexican New York: Transnational lives of new immigrants. Berkeley: University of California Press.

Solinger, D. J. (1999). Contesting citizenship in urban China: Peasant migrants, the state, and the logic of the market. Berkeley: University of California Press.

Suarez-Orozco, M., \& Suarez-Orozco, C. (2001). Children of Immigration. Boston: Harvard University Press.

Sunier, T. (2009). Teaching the Nation: Religious and ethnic diversity at state schools in Britain and the Netherlands. In Holdaway, Crul and Roberts, (Eds). Educating Immigrant Youth: Pathways to Mobility and Citizenship in International Perspective

Tran, V., \& Donato, K. (2018). "The social provision of healthcare to migrants in the US and in China." China Population and Development Studies, 1

US Commission on Civil Rights. (2018). Public Education Funding Inequity in an Era of Increasing Concentration of Poverty and Resegregation. Washington, DC. January. http://www.usccr.gov/ pubs/2018-01-10-Education-Inequity.pdf

US Department of Education, (2013). For Each and Every Child—A Strategy for Education Equity and Excellence, Washington, D.C., 2013.

Wang, C. (2018). Local Governance in China: Realizing the Citizens' Rights of Migrants. China Population and Development Studies, 1

Wang, X., Luo, R., Zhang, L., \& Rozelle, S. (2017). The education gap of China's migrant children and rural counterparts. The Journal of Development Studies, 53(11), 1865-1881.

Waters, M., Heath, A., Van T., \& Boliver, V. (2013). "Second Generation Attainment and Inequality: Primary and Secondary Effects on Educational Outcomes in Britain and the United States. In Alba and Holdaway, (Eds.), The Children of Immigrants in Schools

Woods, T., \& Hanson, D. (2016). Demographic Trends of Children of Immigrants. Urban Institute. October. https://www.urban.org/sites/default/files/publication/85071/2000971-demographic-trends-ofchildren-of-immigrants_2.pdf 
Xiang, B. (2007). How far left behind are the left behind? A preliminary study in rural China. Population, Place and Space, 13(3), 179-191.

Xiong, Y. (2015). The broken ladder: Why education provides no upward mobility for migrant children in China. China Quarterly, 221, 161-184.

Ye, J. (2008). Differentiated Childhoods: Children Left Behind in Rural China. Social Sciences Documentation Press. (In Chinese)

Zhang, Z. (2018). Employment marketization, social security inclusion and rights equalization of rural migrants. China Population and Development Studies, 1.

Zheng, Y. (2007). De Facto federalism in China: Reform and dynamics of central-local relations. Singapore: World Scientific Publishing.

Zheng, Z., He, Z., \& Zhang, Z. (2016). Comparative research on migration in China and the United States. Beijing: China Social Sciences Press.

Zhou, M., \& Bankston, C. (1999). Growing up American: How vietnamese children adapt to life in the United States. New York: Russell Sage Foundation.

Zhou, Y., \& Wang, D. (2016). Understanding the constraints on the supply of public education to the migrant population in China: evidence from Shanghai. Journal of Contemporary China, 25(10), 563-578.

Zhou, M., Murphy, R., \& Tao, R. (2014). Effects of parents' migration on the education of children left behind in rural China. Population and Development Review, 40, 273-292.

Zhou, C., Sean, S., Zhang, L., Luo, R., Yi, H., Liu, C., et al. (2015). China’s left-behind children: Impact of parental migration on health, nutrition, and educational outcomes. Health Affairs, 34(11), 1964-1971

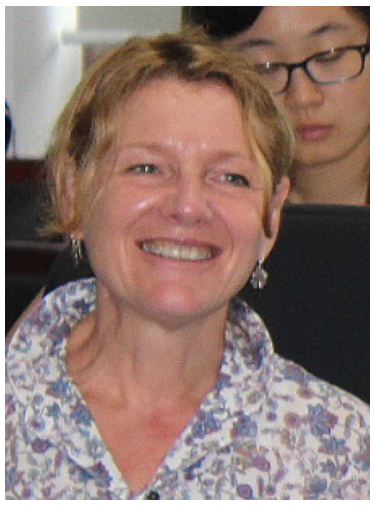

Dr. Jennifer Holdaway Jennifer Holdaway is a Senior Research Fellow at the School of Interdisciplinary Area Studies (SIAS) of the University of Oxford and a Foreign Expert at the Institute of Geographic Sciences and Natural Resources Research, Chinese Academy of Sciences. She is also Co-Director of the Forum on Health, Environment and Development. Prior to joining SIAS she was a Program Director at the Social Science Research Council (SSRC) where she developed interdisciplinary and internationally comparative programs in the field of migration studies and on environment and health. Holdaway has written and edited numerous publications on these topics. For more details see http://www.ccsp.ox.ac.uk/dr-jenni fer-holdaway. 